\title{
DETERMINATION OF THE RATE OF GROWTH OF PACIFASTACUS LENIUSCULUS IN LAKE POBŁĘDZIE, USING POLYMODAL LENGTH- FREQUENCY DISTRIBUTION ANALYSIS
}

\author{
P. ŚMIETANA (1), T. KRZYWOSZ (2)
}

(1) Department of Ecology, University of Szczecin, Poland.

E-Mail: leptosp@univ.szczecin.pl

(2) The Stanisław Sakowicz Inland Fisheries Institute in Olsztyn, Poland.

E-Mail: krzywoszt@infish.com.pl

Reçu le 23 juin 2005

Accepté le 22 décembre 2005

Received June 23, 2005

Accepted December 22, 2005

\begin{abstract}
This study estimated the rate of growth of Pacifastacus leniusculus using the sizefrequency data analysis in Lake Pobłędzie NE Poland. A sample of 1,342 individuals (645 males and 697 females) was collected with baited traps in late September 2002. The age composition of the crayfish population was determined by the Macdonald-Pitcher mixture analysis (computer program MIX. 3.11a) for both sexes separately. Six age groups of males and five of females were identified. The rate of growth was described with a polynomial growth model. The results showed relatively fast increases of both length and weight of Pacifastacus leniusculus in Lake Pobłędzie and no difference in growth rates between males and females. It is concluded from this study that polymodal lengthfrequency distribution analysis can be successfully applied to data on crayfish catches even if juveniles were not completely covered by the sampling method applied. The sampling size needs, however, to be large enough. Further, advantages of applying this analysis are the easy data collected and processing making the method suitable for large data sets already existing, while a disadvantage is the problem of separating the early age classes.
\end{abstract}

Comparison of growth rates among signal crayfish populations suggested a relative fast growth of Pacifastacus leniusculus in Lake Pobłędzie. This population had a faster apparent growth rate than those reported for other crayfish populations from Poland.

Key-words: Pacifastacus leniusculus, growth rate, polymodal length-frequency distribution analysis.

\section{DÉTERMINATION DU TAUX DE CROISSANCE DE PACIFASTACUS LENIUSCULUS \\ DANS LE LAC POBŁĘDZIE À L'AIDE DE L'ANALYSE POLYMODALE DE DISTRIBUTION LONGUEUR - FRÉQUENCE}

\section{RÉSUMÉ}

L'objet de cette étude est une estimation du taux de croissance de Pacifastacus leniusculus dans le lac Pobłędzie, N-E de la Pologne, par l'analyse des données longueurfréquence. Un échantillon de 1342 individus (645 mâles et 697 femelles) a été capturé à 
l'aide de pièges appâtés fin Septembre 2002. La répartition des âges de la population d'écrevisses a été déterminée par l'analyse mixte de Macdonald-Pitcher (logiciel MIX 3.11a) séparément pour chaque sexe. Six groupes d'âge ont été identifiés pour les mâles et cinq pour les femelles. Le taux de croissance a été décrit avec un modèle de croissance polynomial. Les résultats ont montré une croissance relativement rapide à la fois du poids et de la taille de Pacifastacus leniusculus dans le lac Pobłędzie et aucune différence entre les taux de croissance des mâles et des femelles. La conclusion de cette étude est que l'analyse polymodale de distribution longueur-fréquence peut être appliquée avec succès aux données sur les captures d'écrevisses même lorsque les juvéniles ne sont pas totalement pris en compte par la méthode d'échantillonnage. La taille de l'échantillon doit cependant être suffisamment grande. Par ailleurs, les avantages d'utiliser cette analyse sont l'importante quantité de données déjà disponibles et la procédure de mise en œuvre, qui est adaptée à d'importantes séries de données, tandis qu'un de ses désavantages est la difficulté de séparer les classes d'âge juvéniles.

La comparaison du taux de croissance de différentes population d'écrevisses signal laisse suggérer un taux relativement rapide de croissance de Pacifastacus leniusculus dans le Lac Pobłędzie. Cette population a un taux de croissance apparemment plus important que celui trouvé pour d'autres populations en Pologne.

Mots-clés : Pacifastacus leniusculus, taux de croissance, analyse polymodale de distribution longueur-fréquence.

\section{INTRODUCTION}

Programs on the introduction of the signal crayfish, Pacifastacus leniusculus, in waterbodies of Poland were started in 1971 by Prof. Józef Kossakowski and co-workers from the Inland Fisheries Institute in Olsztyn (KOSSAKOWSKI et al., 1978). Monitoring work on the introductions and on the possibilities for farming of this species continued until 1993. However, the results under the conditions prevailing in Poland were quite different from those originally expected.

The first introduction of the signal crayfish to natural water bodies took place in 1972 close to Ełk town (NE Poland). Further trails were carried out between 1975 and 1978 in fishponds close to Działdowo (central Poland). These trials were not successful in terms of the establishment of stable signal crayfish populations. The same was true for an introduction to a 52 ha lake close to Stare Juchy (NE Poland) which was stocked with 25,000 YOY of signal crayfish (GONDKO and GIRSZTOWTT, 1987). Other attempts to establish "controlled" crayfish populations were undertaken in 1979 (2.02 ha lake with 4,200 YOY signal crayfish), and in 1983 (28 adult males and 42 females into lake Szeląg Wielki; 559 ha). These attempts were also not successful. A possible number of reasons for the failure of these introductions were reported. For example KOSSAKOWSKI (1983) suggested pesticide pollution, (GONDKO and GIRSZTOWTT 1987) the effect of dense eel populations, and KRZYWOSZ (unpublished data 2002) the occurrence of Orconectes limosus, and a lack of technical background during the introduction works (KRZYWOSZ, 1994), whilst ŚMIETANA suggested high levels of eutrophication (ŚMIETANA, unpublished data) as a main reason.

However, during the programme on "Active protection of native crayfish in Poland" (ŚMIETANA et al., 2004a), several sites for Pacifastacus leniusculus were recently described in Poland. All of them, except from one crayfish farm, were the result of non-controlled and illegal introductions. Therefore it is very difficult to determine today where the re-stocking material came from. The sources of material were obviously very diverse even including transport by private plane directly from Sweden (ŚMIETANA, unpublished data). 
The history of the presence of signal crayfish in the Pobłędzie Lake, however, is relatively well documented (KRZYWOSZ and KRZYWOSZ, 2002). A mass mortality of the dense populations of Astacus astacus originally inhabiting this lake was observed here in 1989 and was probably caused by pesticide pollution. The signal crayfish was stocked in 1992 with about 1,000 individuals (1+). According to KRZYWOSZ and KRZYWOSZ (2002) nowadays this lake has co-occurring stocks of three crayfish species, i.e. very few Astacus astacus, numerous Orconectes limosus and very abundant Pacifastacus leniusculus.

The importance of signal crayfish in Polish water bodies is not very well documented since there exists only a small number of stocks of this species in Poland. However, a growing interest in crayfish farming in Poland has resulted in an ongoing fast spreading of this species in natural water bodies. Knowledge of the ecology of this species in Poland is important for the assessment and prediction of its impact on Polish surface waters and other crayfish species.

According to NYSTRÖM and STRAND (1996), the impact of Pacifastacus leniusculus on an ecosystem should be similar to that of Astacus astacus, because it has the same food preferences. However, as $P$. leniusculus grows much larger, has a higher fecundity and a higher rate of growth, a greater impact of $P$. leniusculus on ecosystems is likely. For this reason, the determination of the individual growth rate is one of the most important population features, which, however, has only rarely been determined in crustaceans. The absence of stable hard body structures complicates the estimation of age, growth and mortality in all crustaceans (FRANCE et al., 1991).

The mean individual growth rate is one of the characteristics of a population, which might be related to habitat quality, level of adaptation to environmental conditions, and level of interspecific competition.

Apart form sophisticated methods of ageing based on RNA content analyses (EDSMAN et al., 1994; EDSMAN, 1996) or using lipofuscin (SHEEHY, 1989, 1990; BELCHIER et al., 1998), the use of size-frequency distributions to distinguish among modal size groups in order to estimate the rate of growth is a long established method in aquatic sciences. Polymodal frequency distributions of freshwater crayfish have been interpreted by a variety of statistical techniques: probability plot (FRANCE and GRAHAM, 1985), iterative parabola technique of (TANAKA, 1962) and mathematical programs of MACDONALD-PITCHER (SOMERS, 1987, after FRANCE et al., 1991).

The advantage of these methods is the relatively easy access to input data, which are usually measured body length distributions within populations. Almost all ecological research on crayfish populations is based on samples, which consist of a number of crayfish collected by trapping techniques. However, the effectiveness of these techniques specifically for catching juveniles has often been questioned (DAVIES, 1989; FRANCE et al., 1991). FRANCE et al. (1991), therefore suggested using trapping in combination with SCUBA diving in order to obtain all age classes represented in the population and to be able to apply polymodal frequency distributions to datasets of about 200 individuals. As it is very often difficult to use SCUBA diving as an additional method and as there might be large data sets existing from trapping efforts with an underestimation of juveniles, the applicability of polymodal frequency distributions for the estimation of individual growth using only trapping data was tested by the present study. In order to provide a valid database, data from more than 1,300 individuals was used.

\section{MATERIALS AND METHODS}

A total of using 1,342 individuals (645 males and 697 females) was collected with baited traps (roach captured in the same lake) in late September of 2002 in Lake Pobłędzie (NE Poland) about $30 \mathrm{~km}$ north of the town of Suwałki. The period of sampling was 
defined according to former observations on moulting of Pacifastacus leniusculus in Lake Pobłędzie. Samples were collected after the last moulting before wintering to ensure that the majority of individuals were in intermoult stage. Sixty Swedish type traps (mesh size $1 \mathrm{~cm}$ ) were placed along the lakeshore around $7 \mathrm{pm}$. at a depth of 1-3 m. Each trap was emptied every 3 hours. Catching was conducted throughout three subsequent nights. The collected crayfish were not returned to the lake until completion of the third trapping night. Each collected individual was measured ( $T L=$ total length from tip of rostrum to margin of telson, $\pm 1 \mathrm{~mm}$ ) with a caliper and the wet weight $( \pm 0.1 \mathrm{~g})$ was determined using a portable scale (RADWAG WPE 300).

In sub samples consisting each of 150 males and females, carapace length CL was measured to describe the relationship between total length and carapace length. Results on total length were transferred into corresponding carapace length using the established relationships in order to make comparisons of the data with other studies possible. females.

Histograms of the length distributions were prepared separately for males and

The length - frequency histograms were used for the determination of growth rates. Polymodal length-frequency distribution analysis based on the mathematical program MIX 3a (MACDONALD and PITCHER, 1979) was applied. This method provides a graphical basis for differentiating mixed distributions into their parts and then interpreting the separate modes as individual age-groups (FRANCE et al., 1991).

The accuracy of fit was tested by a goodness-of-fit $\chi^{2}$ test.

As the von BERTALANFFY's model did not fit well, the polymonial model was used for the description of growth rates (RYBCZYK and SZYPUŁA, 2005):

$\mathrm{TL}_{\mathrm{t}}=\mathrm{a}+\mathrm{bt}+\mathrm{ct}^{2}$

where:

$\mathrm{TL}_{\mathrm{t}}$ - total body length $\mathrm{TL}$ at age $\mathrm{t}$

$\mathrm{t}$ - age (years)

a, b, c - empirically evaluated parameters.

Using the described relationship for the total length against body mass, with the power function:

$W=\alpha T^{\beta}$

where:

W - mass (weight of body)

$\mathrm{TL}$ - total length

$\alpha, \beta$-empirically evaluated parameters.

The rate of mass increase was determined as well using the recalculated polynomial model.

$\mathrm{W}_{\mathrm{t}}=\alpha\left(\mathrm{a}+\mathrm{bt}+\mathrm{ct} \mathrm{t}^{2}\right)^{\beta}$

where:

$W_{t}$ - mass (weight of body) at age $t$. 


\section{RESULTS}

A mixture analysis applied to the sample of 645 males using the procedure of MACDONALD and PITCHER (1979) is presented in Figure 1. Six age groups were determined in the collected sample and the mean total lengths together with standard errors are presented in Table 1 together with the results expressed as carapace lengths.

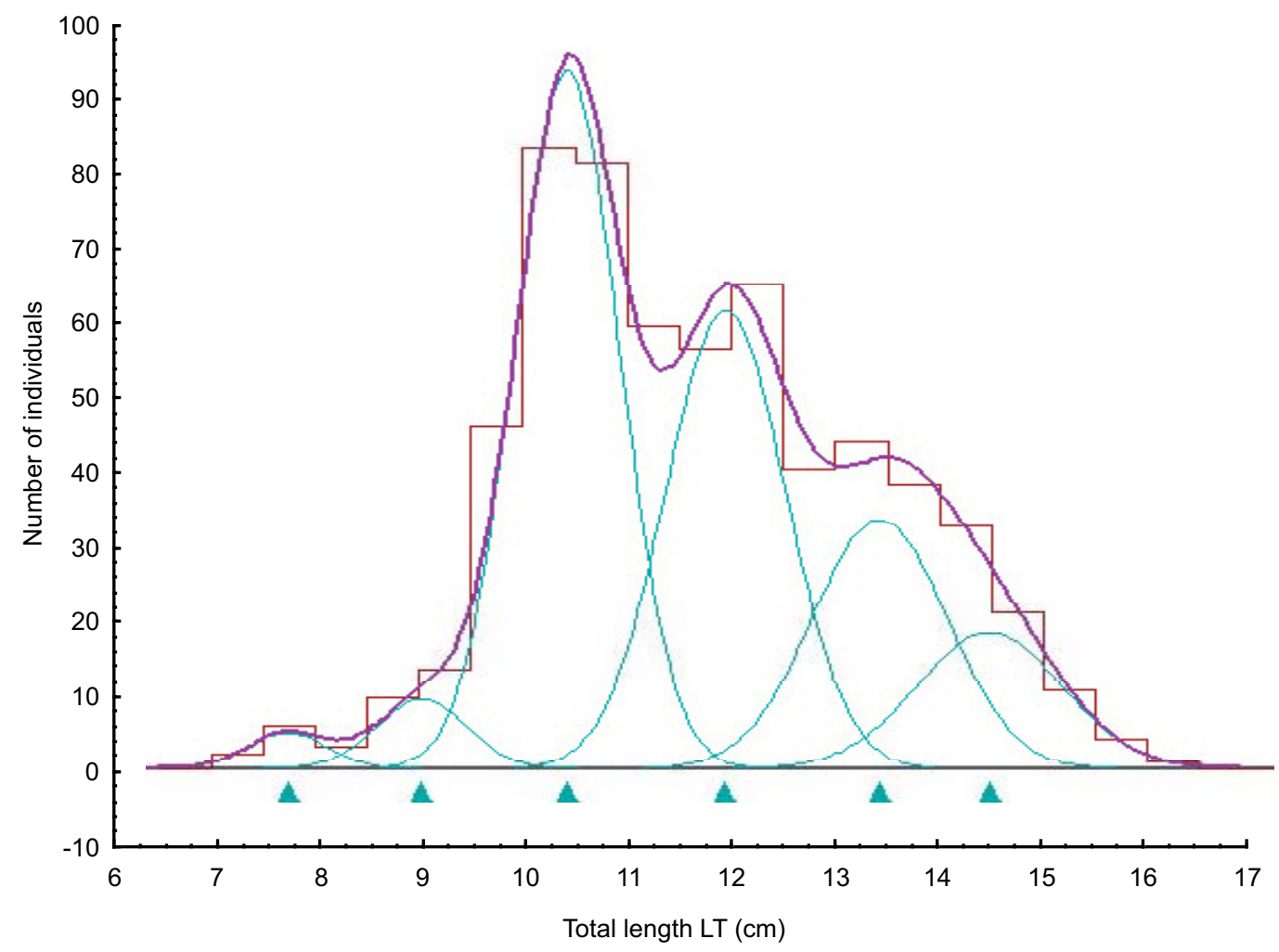

Figure 1

Computer plot of the mixture analysis applied to a sample of 645 males from Lake Pobłędzie, NE Poland, using the procedure of MACDONALD and PITCHER (1979). The thin green (lower) curves represent age-groups; the bold violet (upper) curve represents the fitted total mixture over all age-groups, which should be compared with the histogram. The positioning of the triangles denotes mean sizes of the age-groups.

Figure 1

Résultats informatiques de l'analyse mixte appliquée à un échantillon de 645 mâles du Lac Pobłędzie, N-E de la Pologne, selon la procédure de MACDONALD et PITCHER (1979). Les fines courbes vertes (inférieures) représentent les différentes classes d'âge; la courbe violette (supérieure), plus épaisse, représente le résultat global, toutes classes d'âge confondues, et devrait être comparée à l'histogramme. La position des triangles indique l'âge moyen des classes d'âge. 
The tested accuracy of fit using the goodness-of-fit $\chi^{2}$ test showed an excellent fit of the polymodal curve to the length-distribution histogram $\left(\chi^{2}=4.342 ; \mathrm{df}=8 ; p=0.82\right)$. The best fit was obtained assuming normal distribution of the length within one age group.

Similarly, the results obtained for 697 females are presented in Figure 2 and in Table 2. Five age groups were determined. The fit was acceptable but lower than for males $\left(\chi^{2}=6.385 ; \mathrm{df}=7 ; \mathrm{p}=0.50\right)$.

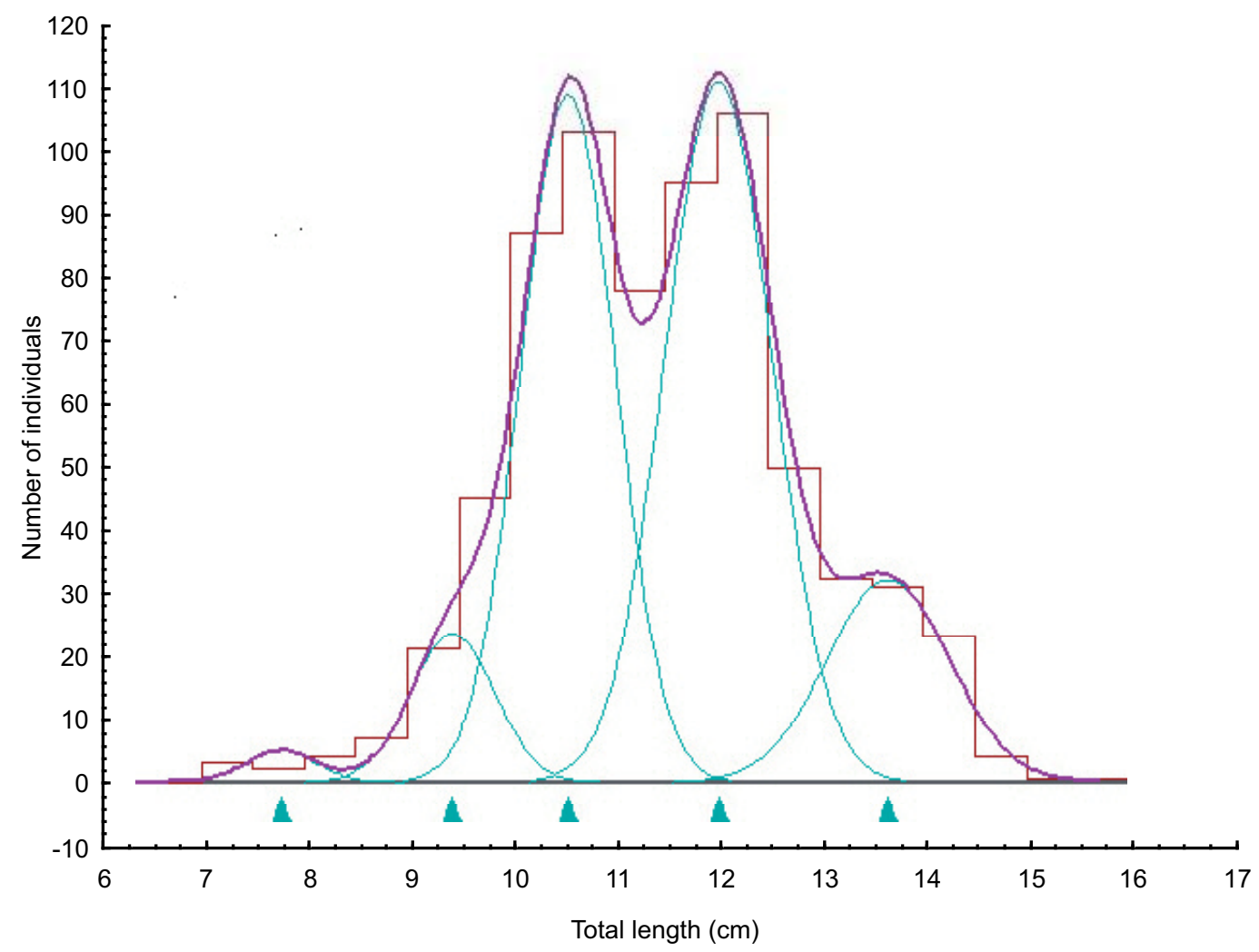

Figure 2

Computer plot of mixture analysis applied to a sample of 697 females from Lake Pobłędzie using the procedure of MACDONALD and PITCHER (1979) Thin blue (lower) curves represent age-groups; bold violet (upper) curve represents the fitted total mixture over all age-groups, which should be compared with the histogram. The positioning of the triangles denotes age-group mean sizes.

\section{Figure 2}

Résultats informatiques de l'analyse mixte appliquée aux 697 femelles du Lac Pobłędzie, selon la procédure de MACDONALD et PITCHER (1979). Les courbes vertes et fines (inférieures) représentent les différentes classes d'âge ; la courbe violette (supérieure), plus épaisse, représente le résultat global, toutes classes d'âge confondues, et devrait être comparée à l'histogramme. La position des triangles indique l'âge moyen de chaque classe d'âge. 
Evaluation of the growth rate curve using the polynomial model resulted in the following equations: $T L_{t}=6.20+1.48 t+0.01 t^{2}$ for males and $T L_{t}=6.56+1.30 t+0.02 t^{2}$ for females (Figure 3): A comparison of the curves did not reveal a significant difference in the growth rates between males and females.

$L T=6.20+1.48 t-0.01 t^{2}$

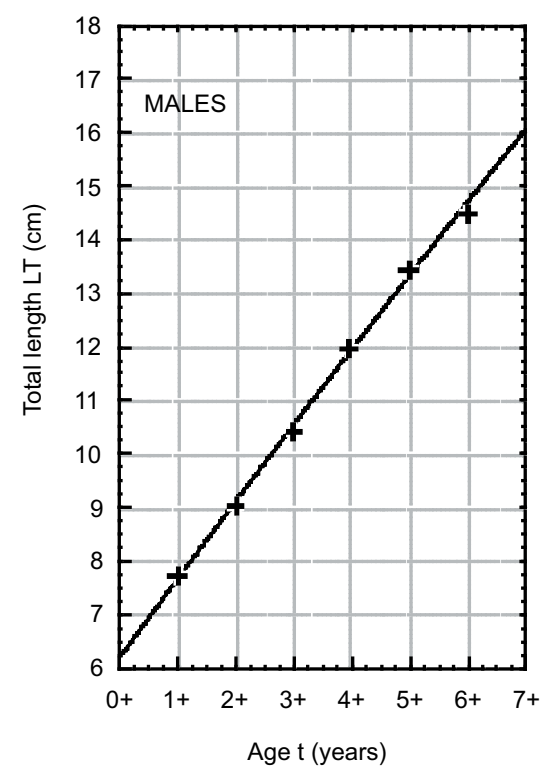

$L T=6.56+1.30 t+0.02 t^{2}$

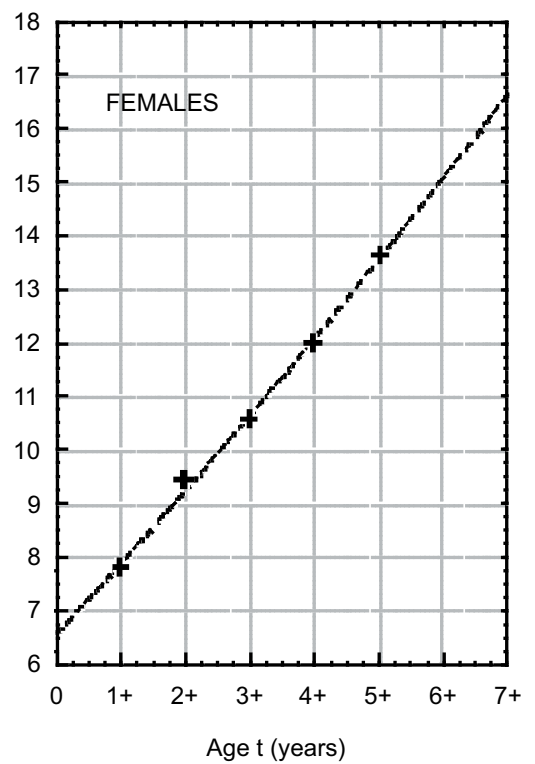

Figure 3

Curves of polynomial linear models (equation denoted above) describing the total length growth rate of males (left graph) and females (right graph) of signal crayfish (Pacifastacus leniusculus) from Lake Pobłędzie, NE Poland. Analysis of the graphs shows a very good fit of the data obtained with polymodal lengthfrequency distribution analysis. The applied model helps to get an image of the mean total length of crayfish within the $0+$ age group.

Figure 3

Courbes du modèle linéaire polynomial (équation donnée plus haut) décrivant la taux de croissance de la longueur totale des mâles (graphe de gauche) et des femelles (graphe de droite), d'écrevisse signal (Pacifastacus leniusculus) du Lac Pobłędzie, N-E de la Pologne. L'analyse des graphes montre une excellente correspondance avec les données obtenues par l'analyse polymodale de distribution longueur-fréquence. Le modèle appliqué aide à estimer la longueur totale moyenne des écrevisses dans la classe d'âge 0 +.

The respective formulas obtained for the weights on the basis of a sub-sample of 100 individuals of both males and female were as follows: For males $\mathrm{W}=0.00813$ TL3.559; $r^{2}=0.89 ; p<0.001$, and for females $W=0.0518 \mathrm{TL}^{2.741} ; r^{2}=0.92 ; p<0.001$.

Using these equations, curves, which illustrate the rate of mass increase were constructed (Figure 4). The observed larger mass of older males (above $3+$ age group) in comparison to females can be attributed to morphological differences, i.e. the size of the claws. 


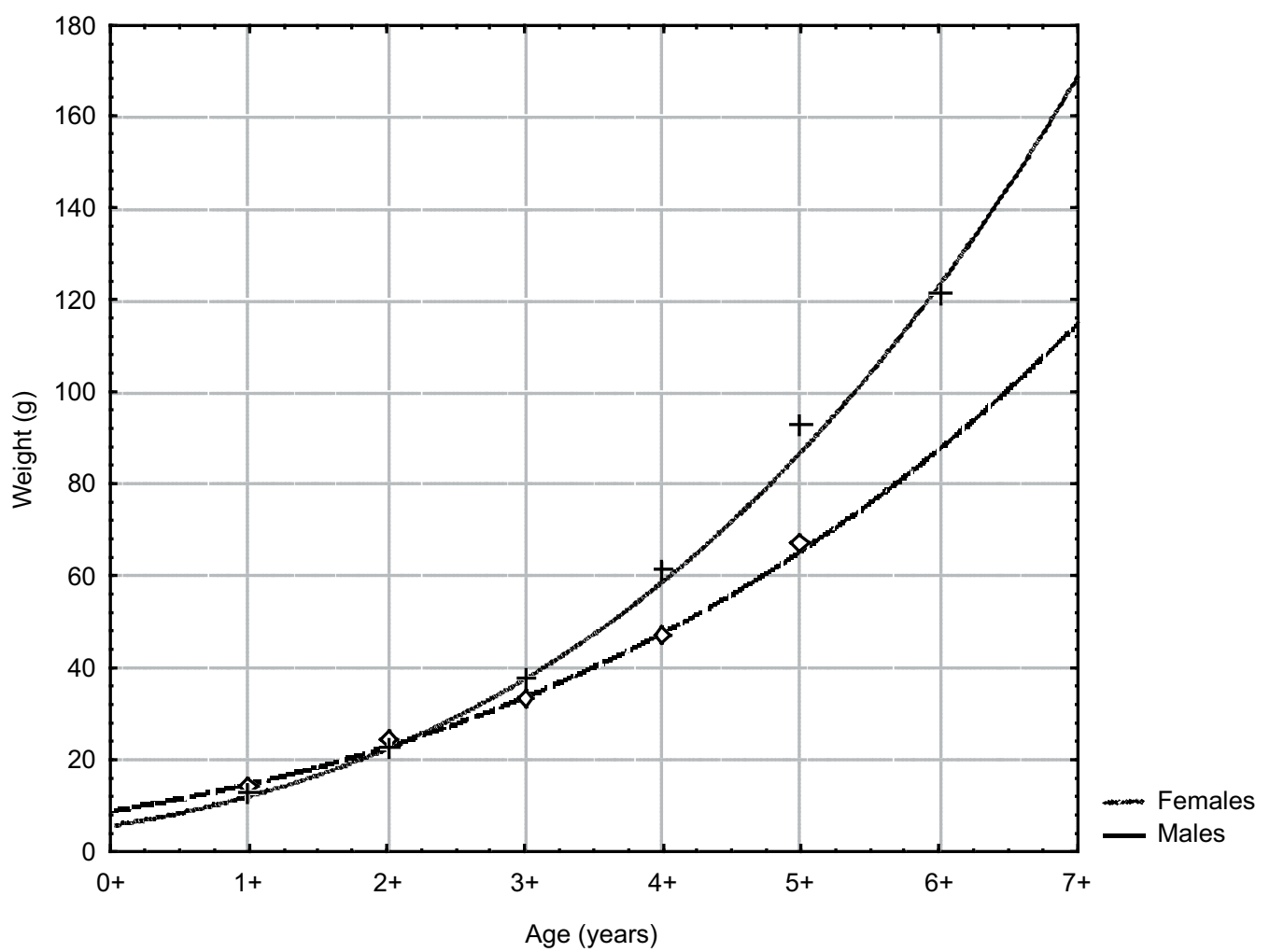

Figure 4

Comparison of the polynomial linear model curves for the rate of weight increase for males and females of signal crayfish $P$. leniusculus from Lake Pobłędzie. The curves were fitted to the "empirical" points (crosses - males; diamonds - females), which denote the mean weight within each age group.

\section{Figure 4}

Comparaison des courbes du modèle linéaire polynomial pour le taux de croissance du poids des mâles et des femelles d'écrevisses signal $P$. leniusculus du Lac Pobłędzie. Les courbes ont été établies à partir des points " empiriques " (croix - mâles ; losanges - femelles), correspondant au poids moyen de chaque classe d'âge.

\section{DISCUSSION}

Signal crayfish from Lake Pobłędzie exhibited a relatively high somatic growth rate, which was also illustrated by body lengths of more than $7 \mathrm{~cm}$ in both males and females from the 1 + age group. However, the mean size of total length within each identified age group may be overestimated by the lack of smaller individuals in the traps. This fact is most likely due to the selectivity of the traps and the intraspecific competition, which resulted in the sole presence of bigger individuals in the traps. Such effects of trapping on length-frequency distributions have been described already by FRANCE et al. (1991). This phenomenon is of specific importance for populations characterized by a low growth rate and when the majority of crayfish is smaller than $24 \mathrm{~mm}$ in carapace length (CAPELLI 1975; FRANCE et al., 1991). These types of problems can, according to (FRANCE et al., 1991) at least be partially solved by combining the trapping method with SCUBA diving. 
In our examination we assumed that the $0+$ age group individuals were not represented in the catch, although, we did not apply the SCUBA method. This assumption is further supported by our own observations on the growth rates of YOY of this species performed in cage experiments conducted under semi-natural conditions, which showed the maximum size within the $0+$ age to be lower than $6.5 \mathrm{~cm}$ total body length (ŚMIETANA et al., 2004b).

However, in the present study we show that a under representation of smaller crayfish due to trapping can be solved by a larger sample size, so that the data can still be used, e.g. for estimations of individual growth rates. The sample sizes of more than 600 individuals of each sex in our study were much larger than those of a minimum of 200 individuals in total as proposed by FRANCE et al. (1991). The larger sample size leads to a decrease of the standard errors and thus contributes to a better separation of the curve components (generations) in the analysis. Additionally, the elimination of the majority of the larger more aggressive individuals during the first catches increased the chance to detect smaller ones in subsequent catches. The phenomenon of catching significantly larger crayfish on the first day of trapping was reported for Astacus astacus populations by KELLER (1999). We found for example only 5\% of individuals belonging to the first two age groups in earlier samples containing mostly large individuals, while the amount of smaller individuals increased to $85 \%$ during the last trapping night exercise, when the larger individuals (above $12 \mathrm{~cm} \mathrm{TL}$ ) were almost absent (below 8\%).

The good fit of the polymodal curve to the length-frequency histograms confirmed a high accuracy of the applied methods and suggests that the rate of length increase described here was representative at least for the populations of males from Lake Pobłędzie. A rather less representative data set was collected for females. Specifically, the $1+$ age group was hardly represented for this sex. These results suggest that females are more sensitive to intraspecific food competition than males. In contrast to the lower rates of growth often reported for females (REYNOLDS, 2002), we did not detect such difference. This can be considered as another hint that the use of the described methodology for growth rate estimation is not as efficient for females. Comparisons of the rates of weight increase showed differences between males and females, which were the result of morphological differences connected to sexual dimorphism. The bigger chelae of the much bigger males are most likely responsible for this difference. Based on the assumption that bigger clawed males have advantages in intraspecific interactions (KELLER and HAZLET, 1996), which then resulted in better access to bait in the traps, the length-distribution for females may be more strongly affected. Therefore, the results on the rate of growth for females are of limited validity.

Despite these potential disadvantages, the methodology used seems to be still valuable in terms of the rate of growth rate analysis. In fact, there are no better methods, describing the growth within crayfish populations requiring a similary small effort. Only permanent marking, e.g. using internal tags, of individuals and their observation through several years may otherwise result in more accurate information on growth rates for crayfish.

The results on growth rates obtained with the presented methodology can be used for comparisons of the growth between different stocks of crayfish or different crayfish species. The comparison of the growth of signal crayfish from Lake Pobłędzie to those reported for other populations is illustrated on Figure 5. Only populations from the UK (HOGGER, 1986) and Sweden (ABRAHAMSSON, 1971) showed a tendency for higher growth. Both of these populations were, however, newly established and introduced to small water bodies, which were characterised rather as ponds than as lakes. Probably this reflects an impact of low densities and reduced competition on the growth of signal crayfish. This assumption seems to be supported by comparisons of growth of cultured populations of signal crayfish. The growth in cultured populations of signal crayfish has been reported by LAURENT (1980) and KRZYWOSZ (1991). 


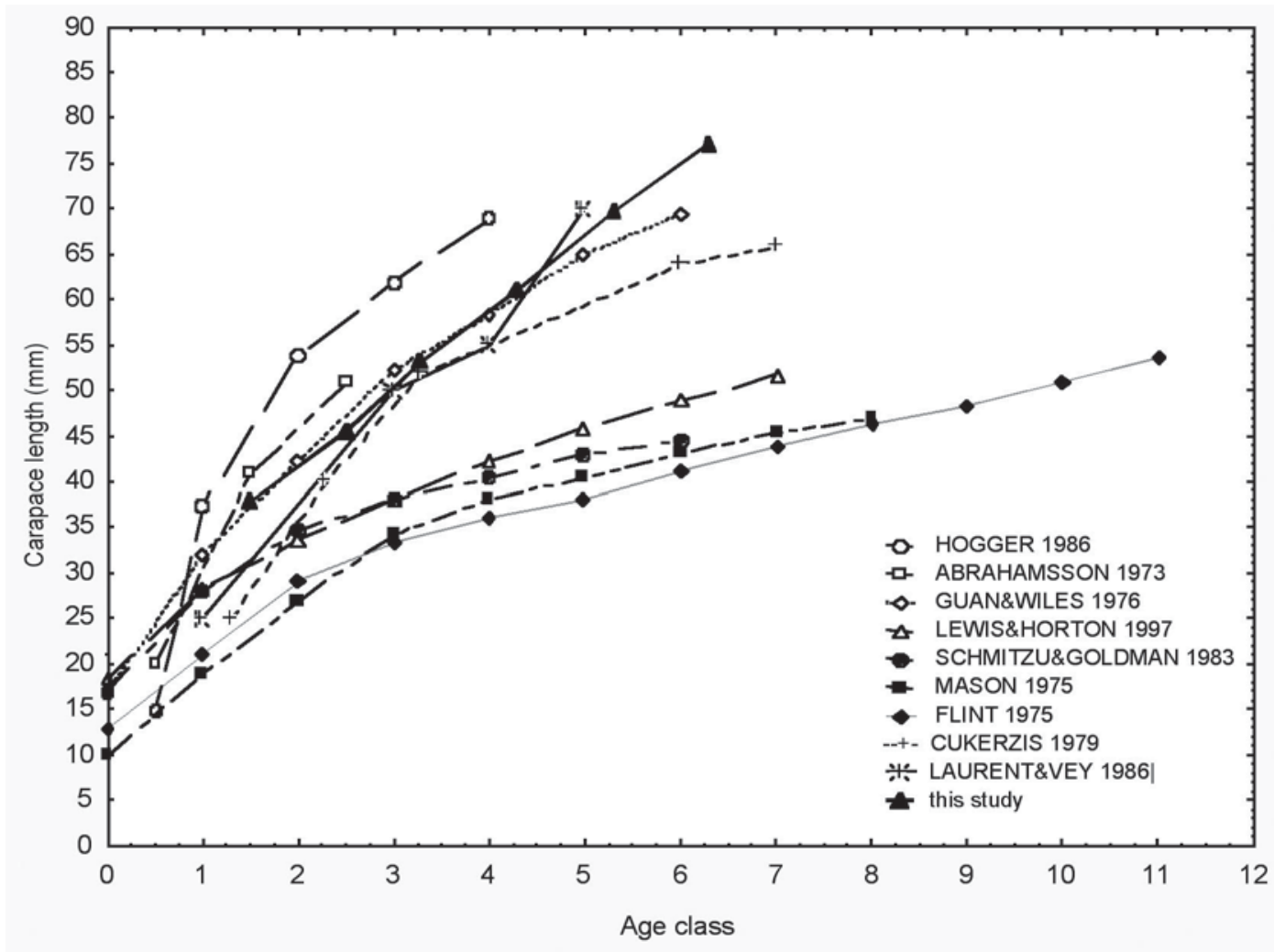

Figure 5

Comparison of the growth curve of the population of Pacifastacus leniusculus from Lake Pobłędzie to other populations.

Figure 5

Comparaison de la courbe de croissance de la population de Pacifastacus leniusculus du Lac Pobłędzie à d'autres populations.

A comparison of signal crayfish from Lake Pobłędzie with other European Pacifastacus leniusculus populations existing under more comparable environmental conditions shows that the growth is relatively similar. Growth curves for signal crayfish from rivers in the UK (GUAN and WILES, 1996) and from a lake in France (LAURENT and VEY 1986) almost overlap the growth curve for the population inhabiting Lake Pobłędzie.

The only differences observed here were for size of the oldest age group. Crayfish from the $6+$ age group in the present study were relatively large compared to data reported by other authors suggesting a continuous fast growth of crayfish from Lake Pobłędzie. Linear growth curves suggest an equal number of moultings per year (LEWIS 2002) usually after about the age of 3 or 4 . The shape of the growth curve of signal crayfish from Lake Pobłędzie indicates a regular sequence of moultings already following the age $1+$. Since the moulting frequency appears to vary according to temperature and food ability (LOWERY and HOLDICH 1988), the obtained results indicated an impact of moderate food limitation on the crayfish growth in Lake Pobłedzie. 
A continuous rapid growth is also obvious from the comparison of the present results to data on growth from a Lithuanian lake (CUKERZIS, 1979), where specimens older than 4 year are distinctly smaller. This is probably a result of the shorter growing season and lower water temperatures at this latitude. The slower growth of American populations of signal crayfish (MOMOT, 1984 after MASON, 1975; FLINT, 1975; LEWIS and HORTON, 1997 and SCHMITZU and GOLDMAN, 1988) than European populations might be explained in a similar way (HOGGER 1986).

Comparisons of weight length relationships of Pacifastacus leniusculus from several populations as illustrated in Figure 6 showed that males of signal crayfish form Lake Pobłędzie have a relatively slow weight increase. Since the weight of males is mainly attributed to the chelae growth (FLINT 1975, LEWIS and HORTON 1997), our results suggest some morphological differences such as slender chelae in crayfish from Lake Pobłędzie. This assumption needs further comparative examination and may thus indicate that analysis of chelae growth could give more valuable information on crayfish growth.

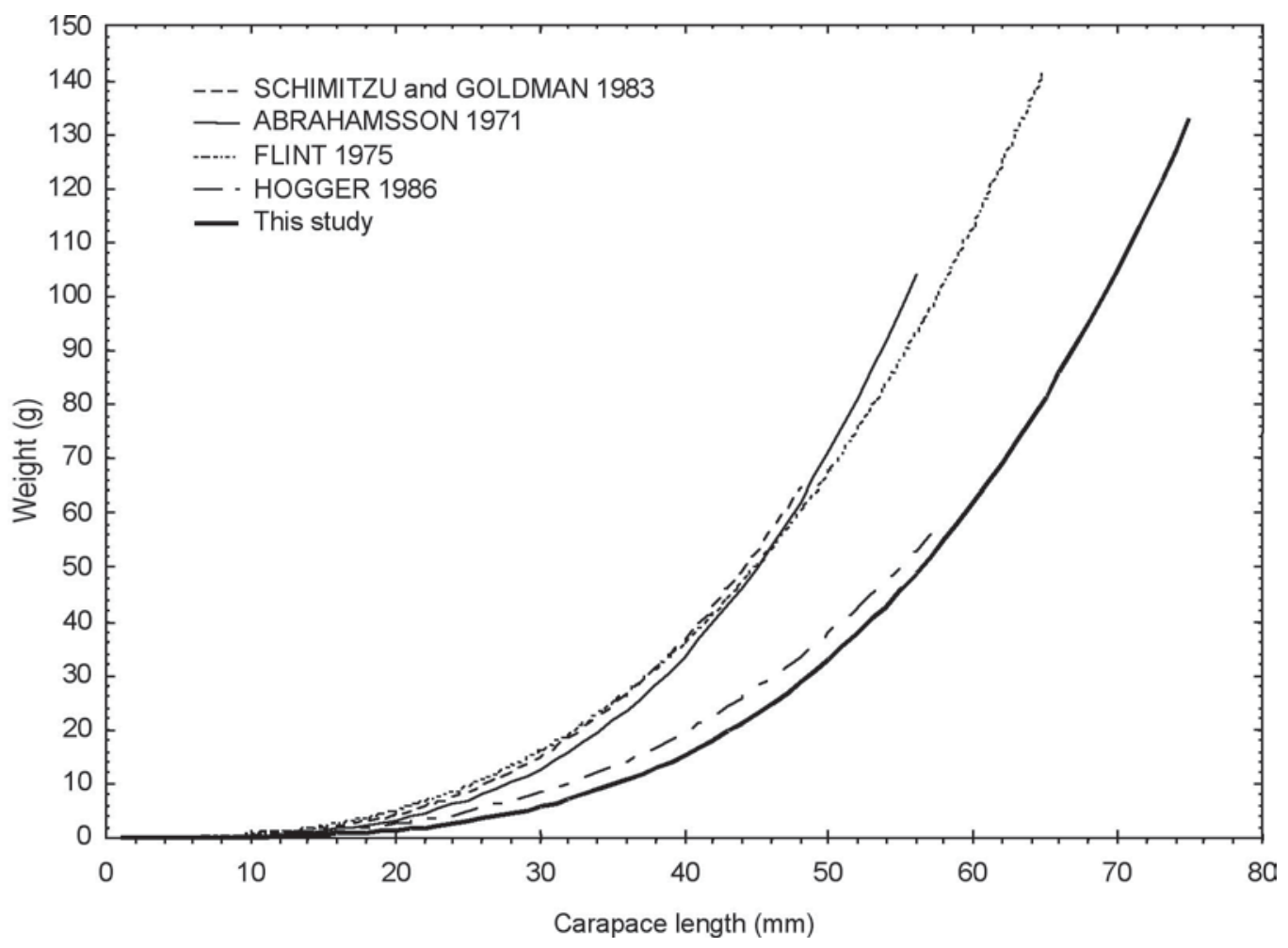

Figure 6

Comparison of weight length relationships of Pacifastacus leniusculus from Lake Pobłędzie to other several populations.

\section{Figure 6}

Comparaison des relations poids-taille de la population de Pacifastacus leniusculus du Lac Pobłędzie à d'autres populations. 
Signal crayfish from Pobłędzie Lake grew relatively faster than other crayfish species from waterbodies of Poland, Lithuania (CUKERZIS, 1989), France and Finland (Figure 7). Particularly large difference was noted in comparison to the growth of Astacus astacus. Already after the first year of life signal crayfish was two times longer than the noble crayfish from a Lithuanian lake and three times longer than those from Finnish lakes.

Signal crayfish form Pobłędzie Lake showed a significantly higher growth than the narrow-clawed crayfish (ŚMIETANA - unpublished) and spiny-cheek crayfish (ŚMIETANA - unpublished, KOSSAKOWSKI, 1966) from Poland and France (JESTIN, 1979). The higher growth rate of signal crayfish can be an important factor in the interspecific competition, which suggests that the signal crayfish in Polish waterbodies may present strong competitors to the other crayfish species.

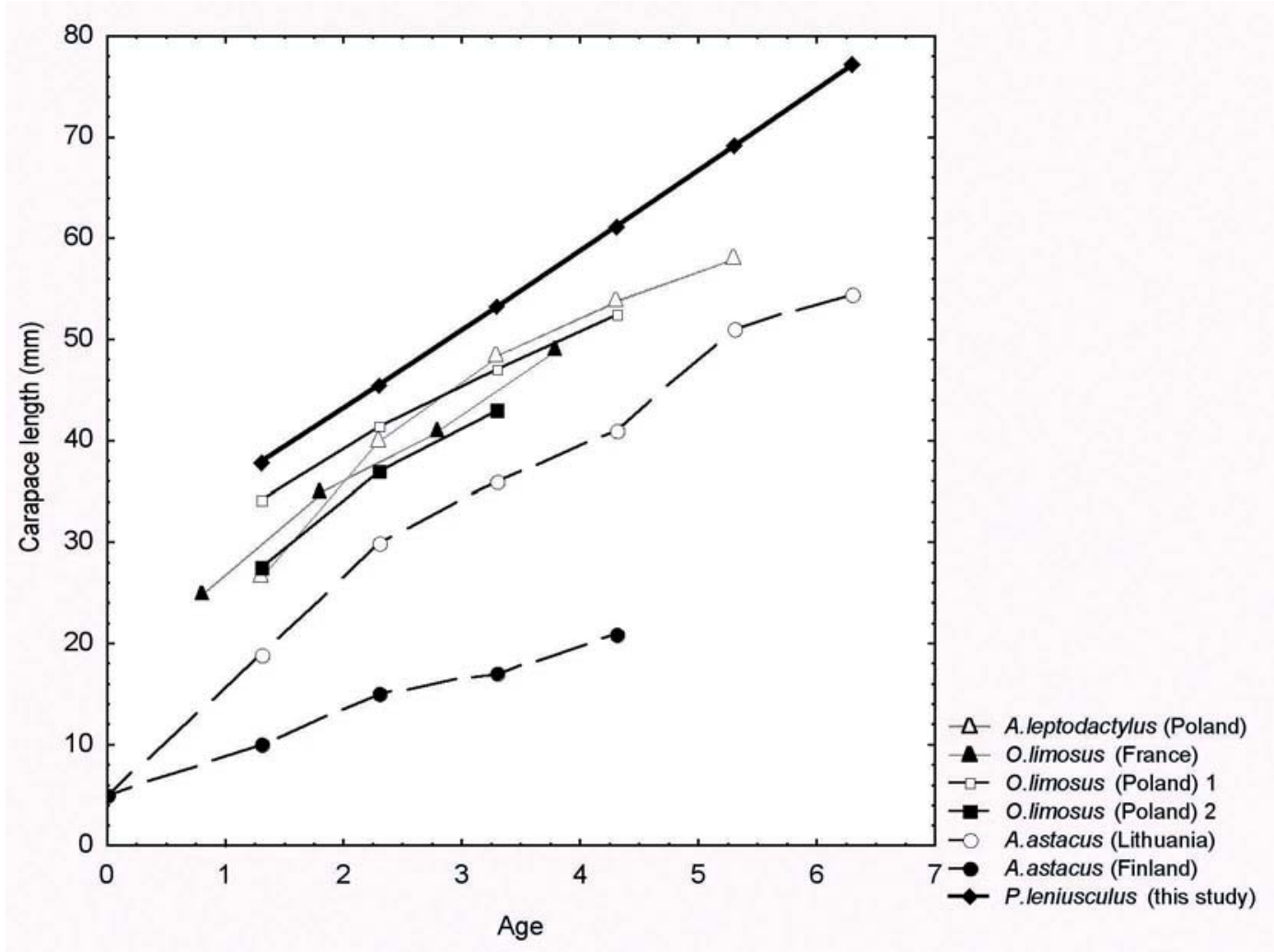

Figure 7

Growth curves of different crayfish species compared to growth curve of Pacifastacus leniusculus from Lake Pobłędzie.

Figure 7

Courbes de taux de croissance de différentes espèces d'écrevisses comparées aux courbes de croissance de Pacifastacus leniusculus dans le Lac Pobłędzie. 
In conclusion, we assume that the use of polymodal length-frequency distribution analysis is an effective and important tool in the examination of growth rates in natural crayfish populations. Although information on sizes of crayfish from younger generations $(0+$ and $1+)$ are lacking, the method can be used to reasonably describe the growth of older crayfish. Through the application of this methodology we can make use of large available data sets on length distribution to derive growth rates, which has so far not been done in many cases. The procedure used allowed us to estimate the growth of signal crayfish from Pobłędzie Lake and to show it as being relative fast in comparison to other populations of the same species and other species distributed in east-central Europe.

\section{ACKNOWLEDGEMENT}

This investigation was financially supported by the Polish Committee of Sciences project No. 3.P04F 072 23. Special thanks are due to Ralf Schulz for valuable help and an anonymous reviewer for important remarks and advice.

\section{REFERENCES}

ABRAHAMSSON S.A.A., 1971. Density, growth and reproduction in populations of Astacus astacus and Pacifastacus leniusculus in an isolated pond. Oikos, 22, 373-80.

BELCHIER M., EDSMAN L., SHEEHY M.R.J., SHELTON P.M.J., 1998. Estimating age and growth in long-lived temperate freshwater crayfish using lipofuscin. Freshwater Biology, 39, 439-446.

CAPELLI G.M., 1975. Distribution, life history, and ecology of crayfish in northern Wisconsin, with emphasis on Orconectes propinquus (Girard): PhD Thesis, University of Wisconsin, Madison, WI. 215 p.

CUKERZIS J.M., 1979. On acclimatisation of Pacifastacus leniusculus Dana in an isolated Lake. Freshwater Crayfish, 4, 445-450.

CUKERZIS J.M., 1989. Freshwater Crayfish. Monograph. Vilnius Mokslas Publishers. 5141. (In Russian)

DAVIES I.J., 1989. Population collapse of the crayfish Orconectes virilis in response to experimental whole-lake acidification. Can. J. Fish. Aquat. Sci., 46, 910-922.

EDSMAN L., 1996. The relative influence of age and body size on the instantaneous growth rate in signal crayfish, Pacifastacus leniusculus. Freshwater Crayfish, 11, 395-402.

EDSMAN L., JÄRVI T., NIEJAHR B., 1994. The RNA concentration as an index of current growth rate in juvenile signal crayfish, Pacifastacus leniusculus. Nordic Journal of Freshwater Research, 69, 149-152.

FLINT R.W., 1975. Growth in a population of the crayfish Pacifastacus leniusculus from a subalpine lacustrine environment. J. Fish. Res. Board Can., 32, 2433-2440.

FRANCE R., GRAHAM L., 1985. Increased microsporidian parasitism of the crayfish (Orconectes virilis) in an experimentally acidified lake. Water Air Soil Pollut., 26, 129-136.

FRANCE R., HOLMES J., LYNCH A., 1991. Use of size-frequency data to estimate the age composition of crayfish populations. Canadian Journal of Fisheries and Aquatic Sciences, 48, 2324-2332. 
GONDKO R., GIRSZTOWTT Z., 1987. Zasiedlanie wód Polski nowym gatunkiem raka, Pacifastacus leniusculus (Dana). Kieleckie Studia Biologiczne, 4, 1-23 [in Polish].

GUAN R., WILES P.R., 1996. Growth, density and biomass of crayfish. Pacifastacus leniusculus in a British lowland river. Aquatic Living Resources, 9, 265-272.

HOGGER J.B., 1986. A report on some of the first introductions of Pacifastacus leniusculus into the UK. Freshwater Crayfish, 6, 134-145.

LOWERY R.S., HOLDICH D.M., 1988. Pacifastacus leniusculus in North America and Europe, with details of the distribution of introduced and native crayfish species in Europe. In: HOLDICH D. M. and LOWERY R.S., Freshwater Crayfish: Biology, Management and Exploitation, 283-308, Croom Helm, London.

JESTIN J.M., 1979. Croissance et développement de l'écrevisse américaine, Orconectes limosus (Rafinesque), dans le lac de Créteil (France). Freshwater Crayfish, 4, 6672.

KELLER M., 1999. Ten Years of Trapping Astacus astacus for Restocking in Lake Bronnen, a Gravel Pit in Bavaria. Freshwater Crayfish, 12, 518-534.

KELLER A.T., HAZLET B.A., 1996. Mechanical use of crayfish chelae. Mar. Fresh. Behav. Phisiol. Vol. 28, s. 149-162.

KOSSAKOWSKI J., 1966. Raki. PWRiL. Warszawa, 5-292 (In Polish).

KOSSAKOWSKI J., MNICH M., KOSSAKOWSKI G., 1978. The first introduction of crayfish Pacifastacus leniusculus Dana. into Polish waters. Freshwater Crayfish, 4, 195.

KOSSAKOWSKI J., 1983. Some remarks on the biology of the crayfish Pacifastacus leniusculus. Roczniki naukowe PZW. 368-376. (In Polish with English abstract)

KRZYWOSZ T., 1994. The introduction of the crayfish Pacifastacus leniusculus (Dana), into Polish waters. Roczniki naukowe PZW, 7, s. 81-93. (In Polish with English abstract)

KRZYWOSZ T., KRZYWOSZ W., 2002. Observations of the signal crayfish Pacifastacus leniusculus (Dana) in a lake in the eastern Suwałki District. Arch. Pol. Fish., 10, 2, 255-267.

LAURENT P.J., 1980. Utilisation des étangs pour la production d'écrevisses. In: La Pisciculture en étang. Ed. R. BILLARD. I.N.R.A. Paris. 333-342.

LAURENT P.J., VEY A., 1986. The acclimation of Pacifastacus leniusculus in Lake Divonne. Freshwater Crayfish, 6, 146-155.

LEWIS S.D., HORTON. H.F., 1997. Life history and population dynamics of signal crayfish. Pacifastacus leniusculus in Lake Billy Chinook. Oregon. Freshwater Crayfish, 11, 34-53.

LEWIS S.D., 2002. Pacifastacus. In: HOLDICH D.M. (Ed.), Biology of Freshwater Crayfish, 511-540, Blackwell Science.

MACDONALD P.D.M., PITCHER T.J., 1979. Age-groups from size-frequency data: a versatile and efficient method of analyzing distribution mixtures. Fish. Res. Board Can., 36, 987-1001.

MASON J.C., 1975. Crayfish production in a small woodland stream. Freshwater Crayfish, 2, 449-479. 
MOMOT W.T., 1984. Crayfish production: a reflection of community energetics. Journal of Crustacean Biology, 4(1), 35-54.

NYSTRÖM P., STRAND J., 1996. Grazing by native and exotic crayfish on aquatic macrophytes. Freshwater Biology, Vol. 36 (3), 673-682.

REYNOLDS J.D., 2002. Growth and Reproduction. In: HOLDICH D. M. (ed.) Biology of Freshwater Crayfish. Blackwell Science Ltd., 152-191.

RYBCZYK A., SZYPUŁA J., 2005. Age as well as length and weight growth of crucian carp from the Szczecin lagoon and the Leszczyńskie Lakeland. Electronic Journal of Polish Agricultural Universities, Fisheries, Vol. 8, Issue 3.

SHEEHY M.R.J., 1989. Crustacean brain lipofuscin: an examination of the morphological pigment in the freshwater crayfish Cherax cuspidatus. Journal of Crustacean Biology, 9, 387-391.

SHEEHY M.R.J., 1990. The potential of morphological lipofuscin age-pigment as an index of crustacean age. Marine Biology, 107(3), 439-442.

SCHIMITZU S.J., GOLDMAN C.R., 1983. Pacifastacus leniusculus (Dana) production in the Sacramento River. Freshwater Crayfish, 5, 210-228.

ŚMIETANA P., 1998. Występowanie raków rodzimych w Polsce północno-zachodniej i analiza porównawcza cech ich populacji, ze szczególnym uwzględnieniem raka błotnego (Pontastacus leptodactylus Eschscholtz, 1823). PhD - dissertation. Agricultural University of Szczecin: 1-128 (in Polish).

ŚMIETANA P., KRZYWOSZ T., STRUŻYŃSKI W., 2004a. Review of the national restocking programme "Active protection of native crayfish in Poland" 1999-2001. Bull. Fr. Pêche Piscic., 372-373, 289-301.

ŚMIETANA P., ZAWAL. A., SCHULZ R., 2004b. Assessing impact of signal crayfish Pacifastacus leniusculus Dana on aquatic macrophauna and macrophytes using cage experiment. Freshwater Crayfish, 15, Abstract. p. 52.

TANAKA S., 1962. A method of analysing a polymodal frequency distribution and its application to the porgy, Taius tumifrons. J. Fish. Res. Board Can., 19, 1143-1159.

WESTMAN K., PURSIAINEN M., 1979. Development of the European crayfish Astacus astacus (L.) and the American crayfish Pacifastacus leniusculus (Dana) populations in a small Finnish lake. Freshwater Crayfish, 4, 243-250. 
